\title{
Pedophilia Metaphor in Malay Newspaper
}

\section{Rozaimah Rashidin, Nur Faizzah Mohd Zalkanil, Nor Diyana Saupi \&} Nurrissammimayantie Ismail

To Link this Article: http://dx.doi.org/10.6007/IJARBSS/v11-i5/10059 DOI:10.6007/IJARBSS/v11-i5/10059

Received: 15 March 2021, Revised: 18 April 2021, Accepted: 14 May 2021

Published Online: 29 May 2021

In-Text Citation: (Rashidin et al., 2021)

To Cite this Article: Rashidin, R., Zalkanil, N. F. M., Saupi, N. D., \& Ismail, N. (2021). Pedophilia Metaphor in Malay Newspaper. International Journal of Academic Research in Business and Social Sciences, 11(5), 785795.

\section{Copyright: (c) 2021 The Author(s)}

Published by Human Resource Management Academic Research Society (www.hrmars.com)

This article is published under the Creative Commons Attribution (CC BY 4.0) license. Anyone may reproduce, distribute, translate and create derivative works of this article (for both commercial and non-commercial purposes), subject to full attribution to the original publication and authors. The full terms of this license may be seen at: http://creativecommons.org/licences/by/4.0/legalcode

Vol. 11, No. 5, 2021, Pg. 785 - 795

Full Terms \& Conditions of access and use can be found at http://hrmars.com/index.php/pages/detail/publication-ethics 


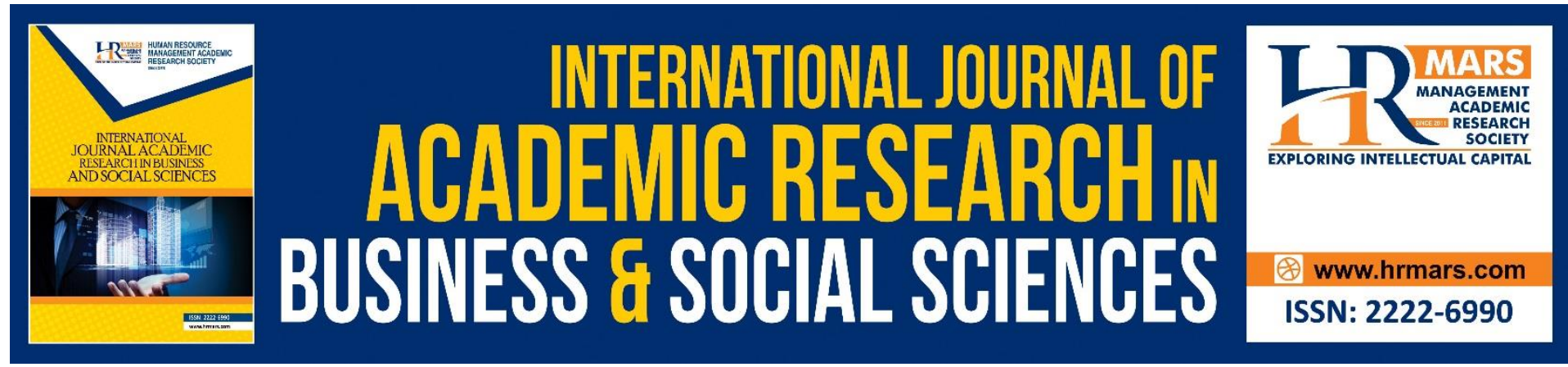

\title{
Pedophilia Metaphor in Malay Newspaper
}

\author{
Rozaimah Rashidin, Nur Faizzah Mohd Zalkanil, Nor Diyana \\ Saupi \& Nurrissammimayantie Ismail \\ Jabatan Pengajian Melayu, Akademi Pengajian Bahasa Universiti Teknologi Mara, Malaysia \\ Email: rozai451@uitm.edu.my
}

\begin{abstract}
The implicit meaning in metaphor has always raised comprehension problems for newspaper readers. This misunderstanding can cause the information or message to be conveyed in a news story to be misunderstood by readers. Due to that, the issues raised do not get the attention of the community due to the difficulties in comprehending information. Therefore, public awareness on issues such as pedophilia crime is increasing in Malaysia and still lacking. Recognizing the importance of accuracy in the use of metaphors conceptualizing the crime of pedophilia, this study was conducted to identify and analyze the forms of metaphor, and thus produce conceptual metaphors that conceptualize criminal pedophilia crimes evident in the Malay newspapers published by NSTP. News in Berita Harian, Berita Minggu, Harian Metro, and Metro Ahad newspapers was used as study data. Study data were obtained from 42 pedophilia crime news articles involving 663 sentences. A total of 96 metaphorical data were analyzed using the Hybrid theory. Data analysis was conducted using content analysis methods. The results of the study found that the conceptual metaphors that are often used to conceptualize the crime of pedophilia are pedophilia is a destroying business, pedophilia is a cancer, pedophilia is a dangerous social relationship, pedophilia is a cheating, pedophilia is a cunning animal character, pedophilia is a war, pedophilia is a slavery, pedophilia is a secret entity, and pedophilia is a cruel monster behavior.
\end{abstract}

Keywords: Metaphor, Conceptual Metaphor, Pedophilia Metaphor, Pedophilia Crime, Hybrid Theory, Malay Newspaper

\section{Introduction}

A metaphor is a comparison between two elements. Thibodeau and Boroditsky (2011) say that the use of metaphor helps to explain complex issues such as criminal matters or news. The community understands more of a concept when a comparison is made. As an example, the metaphor of "Criminals are savages" and "A Crime is like a virus" has changed the perception of the society towards the concept of crime. In the event of comparing crime to the virus, the community would view crime as something that needs to be deleted from continuing to spread. Unlike the comparison of criminals as savages, it will be viewed as something to be conquered and suppressed for some of the crime to never occur again. The implicit meaning in metaphor has always raised comprehension problems for newspaper readers. This misunderstanding can cause the information or message to be conveyed in a news story to be misunderstood by the reader. Due to that, the issues raised did not get the 
attention of the community due to its difficult information to understand. The mastery of aspects of any given language, like using metaphor, enables writer to form ideas in very clear and precise ways (Mokhtar \& Jamil, 2020).

Thus, the use of the correct metaphor is viral in referring to an issue as this involves the understanding of society. It is important to understand the right usage of metaphor as it affects society's thoughts. Hence, the use of metaphor in the prevention of crimes would often affect changes in the legislation. In 1980, Ronald Reagan used the metaphor of War on Drugs which causes the community to change their views on drug addicts and drug dealers as the enemy of society. This clearly shows that the use of metaphor in addressing crime could influence the views of society which leads them to take action against the issue. In short, this proves that the metaphor is the jewel as it has a rather huge impact on influencing the mind of the people to grasp complex ideas such as crimes.

Newspaper reports are usually structured by linguistic grammars, which comprise the words used, sentences formed, and the meanings produced (Mohamad et al., 2017). However, the use of metaphor in the newspaper is also very important. This is because the implication metaphor is able to influence and change the thinking of an individual in comprehending a complex issue. A handful of crime prevention experts mentioned that the use of the wrong metaphor is the cause of the failure of preventing sexual crime. This has been proven through research done by Kelling (1991) against the rape victim in New York. Kelling (1991) said that the victim is not only a victim of rape but also a victim of the wrong usage of metaphor. As a result, the authorities believed that their job was merely to catch criminals but not for preventing it. All this happend due to the effect of the use of metaphor who views the task of the police as to only protect rather than preventing the crime. Therefore, the accuracy of the use of metaphors is important in ensuring that the community can understand the issue that is highlighted in the media.

The scope of the crime in Malaysia is complex and presents a great challenge because of the sophisticated operation of the crime with strong chain of networks (Suppiah, Kaur, Arumugam \& Shanthi, 2019). Crime can be classified into several divisions regarding the offense committed, namely Civil Criminal and Criminal Penal Code. Sexual crimes are categorized in a cluster criminal penal code following the justification of acts and consequences onto the victim. This is because sexual crime is a criminal act that could give a negative impact on the victims. The effect of this can be seen especially through children as it may harm their growth and affect their future. This can be proved through the study of pedophiles. One of the causes of being pedophilia is due to their horrible past of being one of the victims of sexual crime (DiChristina, 2009). Pedophilia crimes happen when a person attacks sexual acts against children such as rape, obscenity, and sodomy. This statement is supported by Becker's psychiatrist stating that an individual who commits sexual crimes to children belongs to the pedophilia. However, looking at the highlights of pedophilia, the statement issued by the American Psychiatric Association (APA) classifies pedophiles in the Mental Disorders and Statistics of Mental Disorders (DSM) since 1968, as individuals who are said to have repeated sexual intimacy or stimulation to children times without having to commit a sexual assault. Recognizing the importance of accuracy in the use of metaphors conceptualize the crime of pedophilia, this study was conducted to identify the forms of metaphor, analyze forms of metaphor and thus produce conceptual metaphors that conceptualize criminal pedophilia crimes by the news writer in the Malay newspapers published by NSTP. This research applies the Hybrid Theory to analyze data. 


\section{Method}

The data is taken from the News Image Bank (NIB) database under the News Street Times (NSTP) company. The NIB database is used in this study due to the methodology of corpus data using original data and actual words. A corpus is a subset of electronic texts library developed on a large scale (Sadjirin, Aziz, Nordin, Ismail \& Baharum, 2018). Therefore, the findings of the study will produce real results. However, this study is only focuses on the use of pedophilia crime metaphor, only lexical use of pedophilia is generated from NIB database. News in Berita Harian, Berita Minggu, Harian Metro, and Metro Ahad newspapers was used as study data. The rationale, the newspaper was among the tabloid newspaper that is Malay language in Malaysia, which registered the highest number of readers in Malaysia. This study only uses pedophile crime data taken from 2013 to September 2017. Rationally, from 2012 to 2017 shows an increase in pedophilia cases in Malaysia. Study data were obtained from 42 pedophilia crime news articles involving 663 sentences. As a result, there were only 96 corpus data with metaphors that were analyzed with the Hybrid Theory framework. All of the following are part of the corpora representing the metaphors of pedophilia.

\begin{tabular}{|l|l|}
\hline \multicolumn{1}{|c|}{ Sample of Corpus Data } & Conceptul Metaphor \\
\hline $\begin{array}{l}\text { Harian Metro (18/2/14)... Ketika kampung terpencil itu mendapat } \\
\text { perhatian, pihak berkuasa dan badan yang memperjuangkan hak } \\
\text { kanak-kanak berkata, industri lucah itu berjangkit dan merebak } \\
\text { dengan pantas di kebanyakan kawasan di Filipina... } \\
\text { (Translation: Harian Metro (18/2/14)... When the remote village } \\
\text { got attention, the authorities and the child rights movement said } \\
\text { that the porn industry is contagious and spreading rapidly in } \\
\text { most areas of the Philippines ...) }\end{array}$ & \\
\hline $\begin{array}{l}\text { Harian Metro (6/2/17)... Kewujudan kes membabitkan jenayah } \\
\text { seksual kanak-kanak atau pedofilia perlu ditangani dengan baik } \\
\text { sebelum menjadi 'barah' yang sukar dikawal dalam kalangan } \\
\text { masyarakat negara ini. } \\
\text { (Translation: Harian Metro (6/2/17)... The existence of cases } \\
\text { involving child sex crimes or pedophilia needs to be handled well } \\
\text { before it becomes a 'cancer' that is difficult to control among the } \\
\text { people of this country.) }\end{array}$ & CANCER \\
\hline $\begin{array}{l}\text { Harian Metro (18/2/14)... Namun menurut pekerja sosial, seorang } \\
\text { wanita Filipina yang dipercayai menganggotai kumpulan } \\
\text { penjenayah datang ke kampung berkenaan beberapa tahun lalu } \\
\text { dan memperkenalkan skim cepat kaya kepada penduduk di situ. } \\
\text { (Translation: Harian Metro (18/2/14)... But according to social } \\
\text { workers, a Filipino woman believed to be a member of a criminal } \\
\text { group came to the village a few years ago and introduced a get- } \\
\text { rich-quick scheme to the residents there. }\end{array}$ & PEDOPHILIA IS A \\
\hline $\begin{array}{l}\text { Berita Harian (14/6/16)... kadang-kadang amat sukar } \\
\text { untukmengenal pasti karakter dan perlakuan seseorang } \\
\text { sukarelawan yang bersifat khianat umpama musang berbulu } \\
\text { ayam. }\end{array}$ & \\
\hline & \\
\hline
\end{tabular}




\begin{tabular}{|c|c|}
\hline $\begin{array}{l}\text { (Translation: Berita Harian }(14 / 6 / 16) . . . \text { sometimes it is very } \\
\text { difficult to identify the character and behavior of a volunteer who } \\
\text { is treacherous like a wolf in sheep's clothing.) }\end{array}$ & \\
\hline $\begin{array}{l}\text { Harian Metro }(18 / 2 / 14) \text {... Mereka memberitahu 'sarang seks } \\
\text { siber' masih terus beroperasi di kampung itu, tetapi tiada } \\
\text { penduduk yang melaporkannya atas faktor keselamatan. } \\
\text { (Translations: Harian Metro }(18 / 2 / 14) \ldots \text { They said the 'cybersex } \\
\text { nest' was still operating in the village, but no residents reported it } \\
\text { due to security reasons.) }\end{array}$ & $\begin{array}{l}\text { PEDOPHILIA IS A } \\
\text { CUNNING ANIMAL } \\
\text { CHARACTER }\end{array}$ \\
\hline $\begin{array}{l}\text { Berita Harian (19/5/16)... Susulan itu, Bukit Aman menubuhkan } \\
\text { Unit Siasatan Seksual Siber Kanak-Kanak (CCSI) bagi } \\
\text { membendung eksploitasi dan serangan seks terhadap kanak- } \\
\text { kanak melalui internet. } \\
\text { (Translation: Berita Harian (19/5/16)... Following that, Bukit Aman } \\
\text { established the Child Cyber Sexual Investigation Unit (CCSI) to } \\
\text { curb the exploitation and sexual assault on children through the } \\
\text { internet.) }\end{array}$ & PEDOPHILIA IS A WAR \\
\hline $\begin{array}{l}\text { Metro Ahad (4/1/15)...dalam dokumen mahkamah dipercayai } \\
\text { Virginia Roberts, 30, mendakwa dia diarahkan 'mengikut segala } \\
\text { kehendak putera itu' oleh rakan Andrew, Jeffrey Epstein, bilionair } \\
\text { Amerika yang juga dikenali sebagai seorang pedofilia ketika parti } \\
\text { liar dianjurkannya. } \\
\text { (Translation: Metro Ahad (4/1/15)...in court documents believed } \\
\text { Virginia Roberts, 30, claimed she was instructed 'according to the } \\
\text { prince's wishes' by Andrew's friend Jeffrey Epstein, an American } \\
\text { billionaire also known as a pedophile when he organized a wild } \\
\text { party.) }\end{array}$ & $\begin{array}{l}\text { PEDOPHILIA IS A } \\
\text { SLAVERY }\end{array}$ \\
\hline $\begin{array}{l}\text { Harian Metro }(18 / 2 / 14) \text {... Mangsa diugut supaya menutup mulut } \\
\text { jika tidak mahu ibu bapa mereka dicederakan. } \\
\text { (Translation: Harian Metro }(18 / 2 / 14) . . \text { Victims are threatened to } \\
\text { shut up if they do not want their parents to be injured.) }\end{array}$ & $\begin{array}{l}\text { PEDOPHILIA IS A } \\
\text { SECRET ENTITY }\end{array}$ \\
\hline $\begin{array}{l}\text { Berita Harian (14/6/16)... Individu seperti ini menyelinap dalam } \\
\text { kalangan masyarakat dan melompat dari satu organisasi ke } \\
\text { organisasi lain dengan membawa cerita hebat dan miliki peribadi } \\
\text { meyakinkan, namun hakikatnya dia adalah seorang raksasa yang } \\
\text { amat rakus dan kejam. } \\
\text { (Translation: Berita Harian (14/6/16)... An individual like this } \\
\text { sneaks into the community and jumps from one organization to } \\
\text { another with great stories and convincing personalities, yet the } \\
\text { fact is that he is a very greedy and cruel monster.) }\end{array}$ & $\begin{array}{l}\text { PEDOPHILIA IS A } \\
\text { CRUEL MONSTER } \\
\text { BEHAVIOR }\end{array}$ \\
\hline
\end{tabular}

The Hybrid Theory is introduced by Tendahl (2009). This theory combines Relevance Theory through the application of the ad hoc concept and also the process of two domain mapping in cognitive-linguistic. Nevertheless, the theory is purified by Stöver (2010) by introducing the Triple Processing Model. Triple Processing involves procedures that complement each other and happen simultaneously in a human's cognitive. Triple Processing involve procedures that complement each other and happen simultaneously in humans 
cognitive. The three processes are simulation process, metarepresentational process and inferential process. Simulation process occurs on the metaphorical utterances phase that is explicit in nature. This process involves literal interpretation of meaning and preposition shaping. In addition, the simulation process will comprise the image schemas formation. This image schemas will form based on the physical experience that one undergoes.

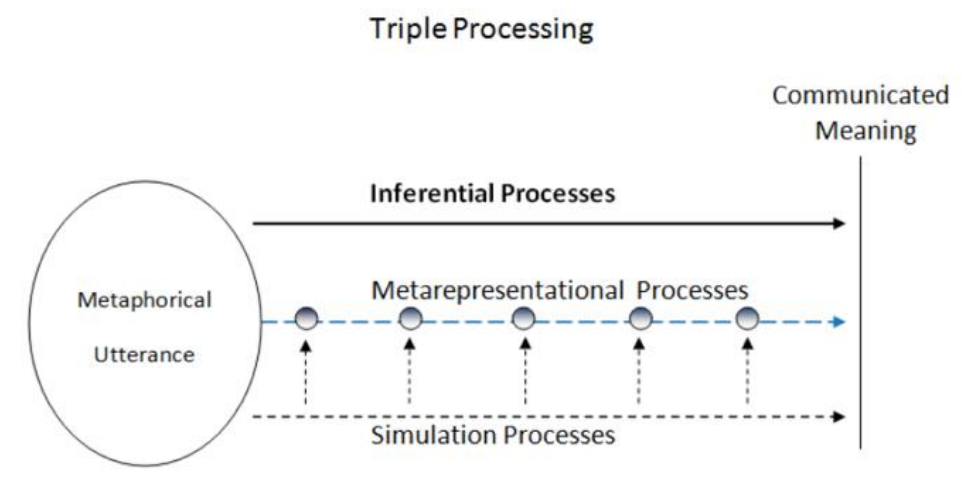

Fig. 1: Triple Processing (Stöver, 2010)

\section{Results and Discussion}

This section discusses in detail and specifically about the metaphorical data process of the sexual crime of pedophilia that is being analyzed systematically using the Hybrid theory. Through the Triple Process which is key to the Hybrid theory (Stöver, 2010), the concept of pedophilia in the tabloid press is described in more detail through the application of ad hoc concepts, image schemes, and domain mapping processes that occur simultaneously in human cognition. Thus, searching for the highlights of the sexual crime of pedophilia is associated with a crime involving prejudice from children. The interpretation of the meaning contained in the expression of data (1a) and (1b) is expressed through the application of the Hybrid theory. Subsequently, this section focuses only on two examples of data analysis involving the application of the ad hoc concept of extension and ad hoc narrowing through the application of Hybrid theory to reveal the implied and implicit meaning of pedophilia metaphorical crime.

(1)a. Harian Metro (1/7/15)... Tanpa disedari, rupa-rupanya ada gambar anak kesayangan kita yang menjadi lauk golongan pedofil di Internet.

(Translation: ...there was a picture of our beloved son that becomes the dish for the pedophile on the Internet.)

(1)b. Berita Harian (14/6/16)...kadang-kadang amat sukar untuk mengenal pasti karakter dan perlakuan seseorang sukarelawan yang bersifat khianat umpama musang berbulu ayam.

(Translation: ...sometimes it is very difficult to identify the character and behavior of a volunteer who is treacherous like a wolf in sheep's clothing.)

Data (1a) is a metaphorical data that is linguistically metaphor because it involves a metaphorical lexical. Through the interpretation process, this data involves the construction of ad hoc narrowing concepts. This is because the process of applying the ad hoc concept of narrowing can facilitate the process of interpreting the meaning. According to Cartson (2002: 
322), the ad hoc concept is a speaker-thinker component that can be interpreted by listeners at a time that is rather specific and temporary. This concept has been pragmatic structured to understand a speech or metaphorical reading. Typically, ad hoc narrowing applications are used to produce specific and distinct meanings according to the verbal expressions. Listeners or readers will code the procedure or concept of the scheme, or the prosecution to obtain the true meaning in the context of the verse other than the meaning of the novel (Cartson, 2002).

In the data (1a), the lexical encyclopedia entry of dish includes meat or fish eaten with rice eater from meat or fish that supports the meaning of live fish in Brunei (Kamus Dewan, 2005: 898). From the various options of the inference, the reader will choose and abrogate the assumptions that are not relevant to the context of the verse. Thus, this has been the narrowing of the meaning of the reader's wishes. Based on the data context (1a), the lexical dish can be interpreted as meaning or reference as a tool or entity that a person uses to pursue or satisfy their lusts. This is because, literally lexical dish entails the meaning of the entity that can be eaten by humans to fill the empty hungry stomach (Dewan, 2005).

However, the interpretation of the meaning which takes into account the overall aberration shows that lexical dish has different meanings of pictures of children on the internet being used as sources for pedophilia to satisfy their lust. Thus, the situation of a pedophile that requires a picture of a child as a source to satisfy his or her lust is equivalent to a situation of someone who needs food to satisfy his appetite. This understanding comes through linguistic evidence through the phrase picture of our beloved son that becomes the dish clearly demonstrates that the lexical dish of the phrase does not mean meat, chicken, or food resources that humans can eat. But, it brings a different meaning to its literal meaning. Therefore, based on the ad hoc narrowing concept, readers will choose the most relevant inferences in the context of the $\mathrm{C}$ (context) of the phrase becomes the dish. Therefore, the desired meaning of a picture of a child uploaded on the internet by some parents has been a source of pedophilia for the pursuit of or liberation of their lusts. Thus, the meaning in $\mathrm{L}$ (lexical) environment is dropped as in the Fig. 2 below.

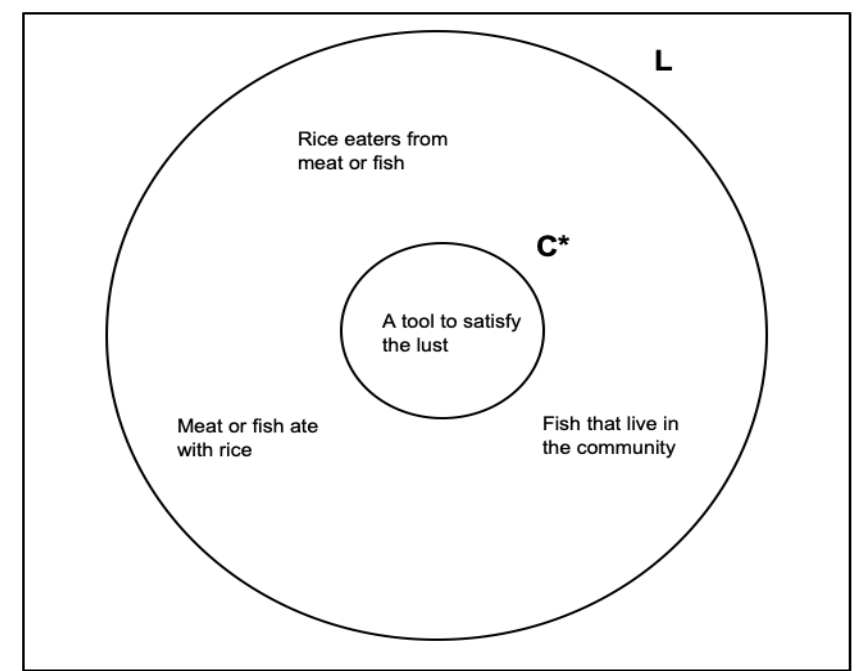

Fig. 2: Ad Hoc Narrowing Concept Mapping for the phrase 'becomes the dish'

Furthermore, the interpretation of the meaning does not stop as far as when it takes into account the entire abrogation. Hence, the data analysis is continued with the involvement of the simulation process, the application of cognitive linguistic approaches, and 
the mapping of two domains, the source domain, and the target domain. This is because, when one gets the selected lexical code, the simulation process that happens simultaneously in cognitive will apply the cognitive linguistic approach as well as the development of two domains. The process indirectly produces an imaging scheme, conceptual metaphor, and metonymy concept. The formation of image schemes will help one to visualize the meaning of metaphorically through the existing knowledge in their cognition. Whereas, the production of conceptual metaphor and metonymy concept also helps one to understand the metaphor by comparing and subsequently given the equation between two different domains. Therefore, the resulting image scheme to conceptualize the phrase into the dish is the image scheme OBJECT. This is because Francisco (2002) has defined the image scheme OBJECT as an experience or entity having interactions with the human body. In simpler language, the image scheme OBJECT is an entity that can be touched and has something to do with one's self. Based on Fig. 2 the phrase to be a dish is linguistic evidence that shows the structure of the image scheme OBJECT has clearly portrayed a picture. In this context, images of small children uploaded on the internet are used as tools for the pedophiles to use them as the material of their appetite which can be compared to the treatment of humans who need food to satisfy their hunger. The dish metaphor that conceptualizes food or food in the phrase to be a dish is an abstract that has been broken down as an entity that feeds predators to satisfy their lust. This phrase involves mapping the source domain ENTITY, which is the FOOD NETWORK OF PREDATOR to the target domain which is PEDOPHILIA to produce a conceptual metaphor that is PEDOPHILIA IS THE FOOD NETWORK OF PREDATOR is as follows:

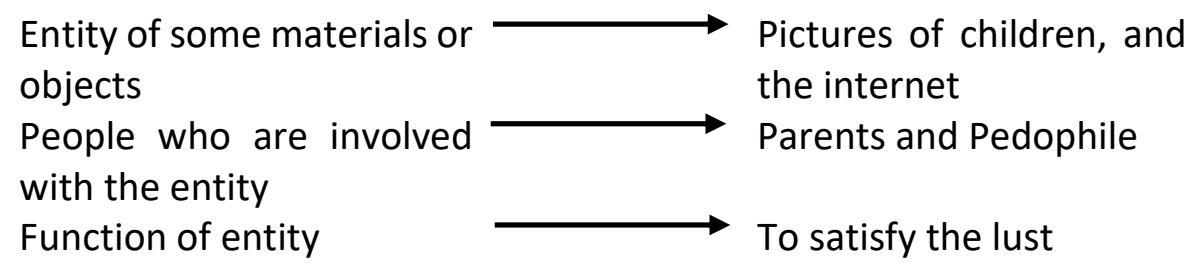

FOOD NETWORK OF PEDOPHILIA

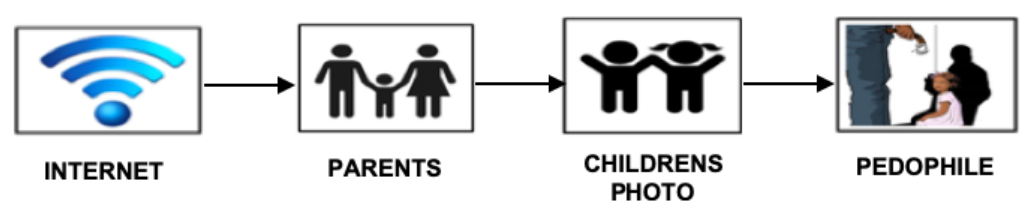

Fig. 3 : Image Scheme OBJECT 'to be a dish'

The involvement of a phrase like a wolf in sheep's clothing in data (1b) also indirectly involves the development of the ad hoc concept of extension. This is because, the ad hoc concept of expansion is focused on the use of metaphorical allegory, symbolic or non-literal expressions. Therefore, the data (1b) like a wolf in sheep's clothing is a conventional metaphor that results from a lexical presence as it pertains to parables. According to Asmah $\mathrm{Hj}$. Omar (2008), in order to understand the verbal perception, indirectly, the listeners will utilize the Optimal Relevance and TR Understanding Procedure to ensure that the cost of processing information is low. In addition, listeners are also willing to use the encyclopedias available in their minds as a basis for conceptual assumptions in the quest for implications. Thus, through the application of the ad hoc concept of expansion, implicative assumptions will be constructed to understand the meaning of the metaphor. 
For data (1b), readers must have sufficient context to interpret meaning like a wolf in sheep's clothing. The explicit phrase is considered to be a rough guide to listeners or readers to understand the wishes of speakers or writers. In the data (1b), the reader will encode the phrase like a wolf in sheep's clothing to get an overview of the meaning of the proverb. This will enable the reader to find the meaning of the lexical concepts or phrases in certain passages logically with the help of a person's physical experience. However, only one of the assumptions that are most relevant to the meaning of the metaphor will be chosen as a conclusion. Data (1b) may result in interpretations or implied assumptions as follows:

i) Camouflage of the wolf using sheep's clothing.

ii) Impersonation of someone who uses a weak person's identity.

iii) A cunning person's impersonation uses the same identity as the person he cheats.

iv) Impersonation of an individual who has a bad intention.

v) Malicious cunning impersonation of individuals to take advantage of weak people.

Data (1b) has resulted in several implicative assumptions that need to be explored implicitly. Interpretation (i) is literally from the meaning, while (ii), (iii), (iv), and (v) is constructed from context. The phrase like a wolf in sheep's clothing does not support the meaning of camouflage of the fox using sheep's clothing instead, it carries the intention of a malicious cunning person. This is because the context of the sentence (1b) is associated with the act of someone who has malicious intent to take advantage of the weak by impersonation. The understanding is based on the linguistic proof of the phrase 'like a wolf in sheep's clothing' itself which supports the implied meaning. According to the experiences of the Malay community, the wolf is known for its cunning nature and always makes camouflage as a source of food for it to catch the chicken.

Therefore, based on this explanation, interpretation (iv) was chosen as an implicative conclusion because of the context of data (1b) that is a pedophile who is willing to impersonate a volunteer to approach children to facilitate the sexual exploitation of them to fulfill their sexual desire. Hence, the phrase 'like a wolf in sheep's clothing' is mapped to the cunning of a pedophile in impersonation to trap the child as a victim to fulfill the needs of his lusts mapped as follows:

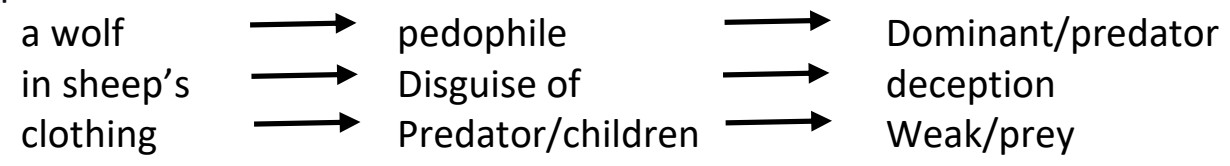

Furthermore, the application of this simulation process will also produce an imaging scheme. For a phrase like a wolf in sheep's clothing, the resulting image scheme is the LINEAR ARRANGEMENT and OBJECT shown in Figure 4.4. The LINEAR ARRANGEMENT of image scheme involves the flow of elements and is associated with time because it has a goal or direction (Johnson, 1987). Francisco (2002), defines an image scheme OBJECT as an experience or entity that has an association with our body and other entities in this universe that is described extensively. The 'wolf in a sheep's clothing' phrase in the data (1b) has revealed the structure of image scheme structure of LINEAR ARRANGEMENT to deceive the child, while the image scheme OBJECT is by pedophile nature mapped as the cunning nature of the Malay culture of the wolf. 


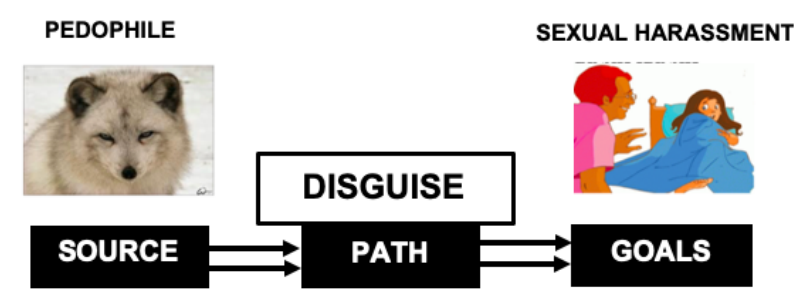

Fig. 4 : Scheme Image of 'like a wolf in a sheep's clothing'

Fig. 4 shows a source of a pedophile that is described as a wolf that has disguised (in a sheep's clothing) as a volunteer in order to achieve his goal of sexual assault on children. The phrase like a wolf in sheep's clothing in the data (1b) illustrates the GOALS that exists in a pedophile represents a flow of time that takes a certain period to be achieved and fulfilled. Based on the LINEAR ARRANGEMENT of the image scheme, the GOAL domain, and the CHARACTER is the source domain mapped to the target domain which is PEDOPHILIA to produce conceptual metaphor PEDOPHILIA IS A CUNNING ANIMAL CHARACTER. Searching for a definition of metaphorical conception has expressed a physical reaction or reference from an abstract entity. Hence, the phenomenon referred to in the data (1b) is the phenomenon of the treatment or the nature of the pedophile referred to as the cunning nature inherent in the characteristics of a wolf. Therefore, the interpretation of the data metaphor (1b) proves that it is very difficult to recognize the real face of a pedophile because of its ability to disguise as common and normal. However, society generally needs to be cautious and sensitive to their children's environment to prevent pedophilia from contagious and spread. Thus, as a whole, linguistic evidence through the interpretation of the pedophile crimes metaphorical suggests that every community should be jointly involved in combating this pedophilia.

\section{Conclusion}

NSTP's published Malay newspaper has highlighted the sexually explicit crimes in Malaysia implicitly through expressions or lexical that deal with the use of the criminal law. The use of metaphors derived from the digital storage press has reflected the accuracy of the use of metaphors is crucial in forming an understanding of the general reader in a particular society. Metaphor is perceived beyond the notion of being the figures of speech, for it is also regarded as a way of thinking and a channel to express information, meaning or implicit messages. The use of the Hybrid theory in analyzing this study helps to produce a dynamic and comprehensive study result. Therefore, the application of Hybrid theory and the utilization of digital bases in the metaphorical aspects of the metaphor may be considered as current and scientific in the field of metaphorical study and general linguistic knowledge. The accuracy of metaphor choices is important in conceptualizing complex issues like sexual crime in Malaysia. The result proves that newspapers authors try to express the victim(s)' feelings in the article writing so that readers in general and specifically the society will be able to take the right actions to ensure the sexual crime rate is kept low by preventing more cases. Hence, this sexual happenings are still present in Malaysia and will continue to happen if writers fail to use the accurate metaphors in newspapers in the future.

\section{Acknowledgements}

This study was conducted under the Fundamental Research Grant Scheme (FRGS/1/2017/ SSI01/UiTM/02/2) sponsored by the Ministry of Higher Education, Malaysia. Researchers 
would like to express our deepest gratitude to Universiti Teknologi MARA and the Ministry of Higher Education for the opportunity given.

\section{References}

Omar, A. H. (2008). Ensiklopedia bahasa Melayu. Kuala Lumpur: Dewan Bahasa dan Pustaka.

Carston, R. (2002). Thoughts and utterances: The pragmatics of explicit communication. Oxford: Blackwell Publishing.

DiChristina, Mariette. (2009). Abnormal Attraction. Scientific American.

Francisco, S. (2002). The Object Image-Schema and Other Dependent Schemas. Atlantis Journal. Vol. XXIV(2), http://search.babylon.com/web/object\%20schema.

Kamus Dewan. (2005). Kuala Lumpur: Dewan Bahasa dan Pustaka.

Kelling, G. (1991). Crime and metaphor: Toward a new concept of policing. City Journal 1.

Mohamad, A., Rashid, R. A., Yunus, K., Abdul Rahman, S. B., Darus, S., Musa, R., \& Teh, K. S. M. (2017). Discourse analysis on newspaper reports of apostasy cases. Journal for the Study of Religions and Ideologies, 16(48), 96-111. Retrieved from www.scopus.com.

Mokhtar, M. M., \& Jamil, M. (2020). Use of figuratives, proverbs, and words of wisdom in argumentative writing: The strategic learning of higher order thinking skills among students. [Penggunaan kata-kata hikmat, tokoh dan peribahasa dalam proses penulisan karangan argumentatif: Strategi penguasaan kemahiran berfikir aras tinggi dalam kalangan murid] Global Journal Al-Thaqafah, 10(1), 58-65. Retrieved from www.scopus.com.

Sadjirin, R., Aziz, R. A., Nordin, N. M., Ismail, M. R., \& Baharum, N. D. (2018). The development of malaysian corpus of financial english (MaCFE). GEMA Online Journal of Language Studies, 18(3), 73-100. doi:10.17576/gema-2018-1803-05.

Stöver, H. (2010). Metaphor and Relevance Theory: A New Hybrid Model. Ph.D disertation. University of Bedfordshire.

Suppiah, P. C., Kaur, S., Arumugam, N., \& Shanthi, A. (2019). News coverage of foreign sex workers in Malaysia: A critical analysis. GEMA Online Journal of Language Studies, 19(1), 136-152. doi:10.17576/gema-2019-1901-08.

Tendahl, M. (2009). A Hybrid Theory of Metaphors: Relevance Theory and Cognitive Linguistics. Great Britain: Palgrave Macmillan.

Thibodeau, P. H., Boroditsky, L. (2011). Metaphors We Think With: The Role of Metaphor in Reasoning. PLoS ONE Vol 6(2). 